\title{
Influence of Leadership and Academic Culture on Academic Quality Assurance in Nursing Vocational Schools in the Era of Industrial Revolution 4.0
}

\author{
Susi Hartati, Mukhneri Muktar, Matin
}

\begin{abstract}
The quality of higher education in Indonesia has not been evenly distributed including vocational nursing schools. The academic quality assurance for nursing vocational schools is not at its best, which has an impact on the quality of nurse's graduates who will provide health services. The purpose of this research is to examine the influence of leadership and academic culture, on academic quality assurance. The quantitative research uses a questionnaire on 122 permanent lecturers at 24 nursing schools. The validity and reliability of the questionnaire were conducted. The hypothesis was tested using path analysis and continued with the goodness of fittest. This paper has explained how leadership and academic culture has a direct positive impact on academic quality assurance. The study also found indicators of directing and academic freedom have a major contribution to academic quality assurance. The influence of leadership and academic culture are discussed. This paper highlights the importance of leadership and academic culture and to academic quality assurance in nursing vocational schools
\end{abstract}

Index Terms: academic quality assurance, leadership, academic culture

\section{INTRODUCTION}

In facing challenges in this global era, Indonesia must build quality higher education so that graduates can compete and be accepted in the global market. Quality higher education is higher education that produces graduates who can actively develop their potential and produce knowledge and technology that is useful for society, nation, and country. Community demands on improving the quality of educational institutions are closely related to the challenges of the competitiveness of the community itself. The higher the level of competence and expertise possessed by the younger generation, the more open opportunities for them to be able to exist and win the competition.

Revised Manuscript Received on September 22, 2019

Susi Hartati, Department of Education Management - Jakarta State University.

Mukhneri Muktar, Department of Education Management - Jakarta State University.

Matin, Department of Education Management - Jakarta State University.
To realize quality higher education, it is necessary to implement a quality assurance/quality assurance system for higher education which functions to control the implementation of higher education. Ketkajorn, Vajarintarangoon, \& Sri-ngan (2017) explain the factors that influence the effectiveness of quality assurance.

Three factors based on high to low values are human resource factors, leadership factors, and teamwork factors. Besides, it was found that different school sizes have different factors that influence the effectiveness of quality assurance. Nurses as one of the largest health workers (80\%) of all health workers are in charge of providing quality nursing care services by their expertise and authority. Nursing vocational schools must be prepared to face a variety of disruptive changes, both in terms of curriculum, learning, research, lecturers competencies, etc. Technological advances in the era of globalization affect the need for quality human resources. There are several factors that influence the implementation of internal higher education quality assurance in Vietnam, namely: (1) leader commitment to quality and implementation of quality assurance; (2) knowledge and expertise in quality assurance; (3) an effective accreditation process with clear standards; (4) clear perspectives on quality assurance (2).

\section{LITERATURE REVIEW}

\section{A. Academic Quality Assurance}

According to Geoffrey Doherty, Quality assurance (QA) a proactive approach which is to identify problems and deal with them immediately, or better prevent them from happening at all (3). Academic quality assurance is a demonstration or verification that the desired level of quality of academic activity has been attained or sustained, or is likely to be attained or sustained. Academic activities generally include teaching, learning, scholarships, research and research training for higher degrees by research. Mechanisms (systems, processes, activities) are employed to verify services that are known as quality assurance systems, quality systems or even just quality assurance (4). The academic quality assurance is involved in the instruction of

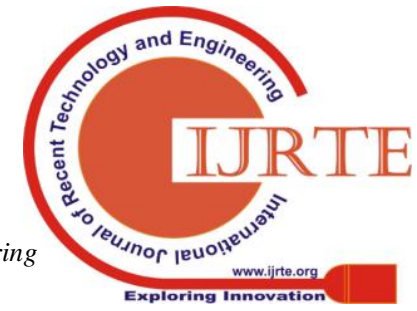


standardized remain students at all times (5).

\section{B. Leadership}

Leadership as the ability to influence a group toward the achievement of a vision or set of goals (6). Leadership is the ability to inspire people to make a total, willingness, and voluntary commitment to accomplish or exceeding organizational goals (7). Leadership is defined as the ability to influence, motivating, and enabling others to contribute to the effectiveness and success of the organizations that they are members (8). Leadership is the process of getting people to do their best to achieve the desired result. It can be described as the ability to match others willingly to behave differently. (9).

\section{Academic Culture}

Academic cultures are characterized by far-reaching complexity compared to business organizations because they combine at least three areas: organizational identity, the professional culture of academics and the culture of a scientific particular discipline (10). Academic culture receives its meaning from an interaction between educational groups on university community levels. The academic culture of communication and interaction among university members. It's also considered as one of the effective determinants of higher education policies (11). Academic culture is the norms, values, beliefs, and practices that work for the members of higher education institutions (12).

\section{METHODOLOGY/MATERIALS}

The study was conducted on permanent lecturers at 24 Nursing Academies in Jakarta. The method used was this quantitative study using survey research techniques, through a Path Analysis approach. Sample size determination uses Proportional Random Sampling with Slovin formula. The population was 195 people. Test samples were 20 lecturers. The number of research samples is 122 lecturers. Validity tests are conducted using Product Moment Pearson and questionnaire reliability testing is done using Cronbach's alpha technique. Then testing path analysis requirements, namely normality test, linearity test, and significance test. The research hypothesis testing was carried out by regression analysis and correlation techniques. Regression analysis is used to predict the relationship model, while the correlation analysis is used. Regression models obtained were tested for significance and linearity using the F test in the ANOVA table. Test the model where the coefficient value of each path must be significant to answer the research hypothesis, then tested the goodness of fitted model to find out the compatibility of the research model with the research data. The final step is testing the hypothesis.

\section{RESULTS AND FINDINGS}

\section{A. Research Hypothesis}

The hypothesis tested in this study (1) Leadership $\left(\mathrm{X}_{1}\right)$ has a direct positive impact on the academic quality assurance
(Y); (2) Academic culture $\left(\mathrm{X}_{2}\right)$ has a positive direct impact on academic quality assurance $(\mathrm{Y})$; (3) Leadership $\left(\mathrm{X}_{1}\right)$ has a positive direct impact on the academic culture $\left(\mathrm{X}_{2}\right)$

\section{B. The Normality Test:}

The test of the analysis requirements used is the normality test. The results of the normality test were all normally distributed populations.

\section{Significance and Linearity of Regression Test}

Hypothesis testing is carried out using regression analysis and correlation techniques. Regression analysis is used to predict the relationship model, while the correlation analysis is used. Regression models obtained were tested for significance and linearity using the $\mathrm{F}$ test in the ANOVA table.

\section{Correlation Calculation}

The calculation results of the correlation coefficients $\mathrm{X}_{2}$ and $\mathrm{X}_{1}(\mathrm{r}=0.761)$, $\mathrm{Y}$ with $\mathrm{X}_{1}(\mathrm{r}=0.69)$, $\mathrm{Y}$ with $\mathrm{X}_{2}(\mathrm{r}=$ $0.74)$, so we can conclude the correlation between variables very significant.

\section{E. Hypothesis Testing}

The results of the hypothesis are : (1) the leadership has a positive direct effect on academic quality assurance; (2) academic culture has a positive direct effect on academic quality assurance; (3) leadership has a positive direct effect on academic culture. The results of testing indicators of leadership variables to academic quality assurance are directing. Indicators of academic culture variables to academic quality assurance are academic freedom. The indicator leadership variable to academic culture is directing.

\section{F. Influence Of Leadership On Academic Quality Assurance}

The first hypothesis it can be concluded that leadership has a direct positive effect on academic quality assurance. Indicators directing have the most significant influence on academic quality assurance. Parvin (2018) explains Leaders are central drivers in quality assurance by implementing their roles and responsibilities, ensuring proper resource allocation, creating partnerships, and optimizing people and process management. Jacobson (2011) explains leadership and professional processes as important to maintain success and change in organizational governance. And according to Yirdaw (2016), leadership factors become the dominant factor concerning service quality and graduates. Institutional leaders have a significant influence on management performance. Directing leadership is the initial or basic leadership style. Directing leadership is needed because lecturers have low competence and motivation, and high commitment. Therefore leaders must spend more time working with lecturers. As a leader, it is necessary to pay great attention to the tasks that must be carried out by the lecturer specifically, clearly, in detail and explain how to complete the task and carry out a regular follow-up. The

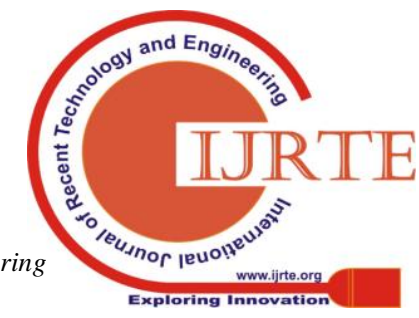


leader must also help solve problems and make decisions when a lecturer cannot do the work or assignments given to him or does not have the confidence to complete the task.

\section{G. Influence Of Academic Culture On Academic Quality Assurance}

Academic freedom indicator has the most significant influence on academic quality assurance. Academic culture is a universal culture that is owned by everyone who engages himself in the academic activities of higher education and promotes academic freedom, upholds scientific truth, objectivity and makes universities not easily influenced or controlled by power or practical political interests. Akhtar, Jalil, Farooq, Afzal, \& Awan (2010) describe academic culture and leadership as found to be important factors for the application of the SAM (Self Assessment Manual) in most universities. QEC (Quality Enhancement Cells). This academic freedom indicator in academic culture is the freedom possessed by the academic community to responsibly and independently carry out academic activities related to the development of science and technology in teaching, research, community service.

The indicator of academic freedom in this academic culture is the freedom possessed by the academic community to be responsible and independent in carrying out academic activities related to the development of science and technology in teaching, research, community service.

Campus as a shared space accommodates expressions of freedom of opinion by existing norms. The campus provides spaces for opinion, expressing ideas, freedom to express criticism, self-criticism, including being open to accepting the results of other people's research, being open to criticism and opinions of others. This academic freedom is a passion for respecting and respecting every difference of opinion. According to Svyatov, Adambekova, \& Amankeldi (2015), the quality of education in educational institutions can increase with the provision of academic freedom to lecturers. This can be done through improving the quality of scientific research, establishing non-binding academic programs, teaching between universities. Pedagogical load management allows lecturers to focus on the quality of education. All of this will encourage universities to change management approaches (17). The academic freedom of understanding and absolute right and not the independence of the teacher (18).

\section{H. Influence Of Leadership On Academic Culture}

Indicators directing have the most significant influence on academic culture.

Leadership has an impact on organizational culture. Leaders must be able to become role models for staff through their words, behavior, and actions (19). Turan \& Bektas (2013) there is a positive and significant relationship between school culture and teacher leadership practices. Karadag \& Oztekin-Bayir (2018) explained that principals' leadership behaviors have a positive impact on teacher's perceptions of school culture. Dill (2012) explains "Universities are culturally loaded organizations, in which values are as objectivity, academic freedom, and respect for students and human subjects. Academic guides are reflected in language, symbols, and ceremonies of academic life." The management of a successful academic culture can determine whether the University can fulfill its responsibilities to the community. Therefore, it is very necessary for the role of university leaders to create a conducive academic culture that is built on the principles of freedom of thought, freedom of speech and an academic pulpit in a dynamic, open and scientific academic atmosphere. Based on the description above, leadership must be improved, it can improve academic culture.it can improve academic culture.it can improve academic culture.

\section{CONCLUSION}

First, directing leadership has a direct influence on academic quality assurance. This means that strong directing leadership will enhance academic quality assurance.

Second, there are academic freedom influences academic quality assurance. Conducive academic freedom makes the academic community feel comfortable doing academic activities on campus.

Third, directing leadership provides an indirect influence on academic quality assurance through academic culture. This means that directing leadership possessed by a leader shows the strength of leadership that can influence the increasingly high academic culture.

\section{ACKNOWLEDGMENT}

This research work is supported by the Department of Nursing -STIKes Mitra Keluarga, Jl. Pangasinan Rawa Semut, Margahayu, Bekasi Timur, Margahayu, Bekasi Timur, West Java, Indonesia.

\section{REFERENCES}

[1] Ketkajorn S, Vajarintarangoon K, Sri-ngan K. Factors Affecting the Effectiveness of Educational Quality Assurance. J Buddh Educ Res. 2017;3(2):48-56.

[2] 2. Do QTN, Pham HT, Nguyen KD. Quality Assurance in the Vietnamese Higher Education: A Top-Down Approach and. In: The Rise of Quality Assurance in Asian Higher Education. Elsevier Ltd; 2017. p. 191-207.

[3] 3. Doherty G. Quality Assurance in Education. In the United Kingdom; 2012. p. 424. Available from: www.intechopen.com

[4] 4. TEQSA. Guidance Note: Academic Quality Assurance What is academic quality assurance ? Vol. 2. Australia: Australian Government; 2017. 1-6 p.

[5] 5. Sylvester S, Ebisine SS. Academic Quality Assurance in the Colleges of Education: Challenges and Ways Forward for Future Development Academic Quality Assurance in the Colleges of Education: Challenges and Ways Forward for Future Development. Int Lett Soc Humanist Sci. 2014;13:0-9.

[6] 6. Robbins ST, Judge TA. Organizational Behavior. Pearson Education Limited; 2012. 259 p.

[7] 7. Goetsch DL, Davis S. Quality Management For Organizational Excellence: Introduction to Total Quality Seventh Edition. 7th ed. Edinburgh: Pearson Education Limited; 2014. 472 p.

[8] 8. Mc Shane SL, Von Glinow MA. Organizational Behavior: Emerging Knowledge and Practice For The Real World. 8 th. McGraw-Hill/Irwin. 2010. 1-669 p.

\section{Published By:}

Blue Eyes Intelligence Engineering 
[9] 9. Armstrong M. Armstrong 's Handbook of Management and Leadership for HR. 4 th. London: Kogan Page Ltd; 2016. 472 p.

[10] 10. Clark BR. Burton Clark's The Higher Education System: Academic Organization in Cross-National Perspective. London Rev Educ. 2010;8(3):229-37.

[11] 11. Sarmadi MR, Nouri Z, Zandi B, Lavasani GM. Academic culture and its role in knowledge management in the higher education system. Int J Environ Sci Educ. 2017;12(5):1427-34.

[12] 12. Szelenyi K, Rhoads RA. Academic culture and citizenship in transitional societies: case studies from China and Hungary. High Educ. 2013;66(4):425-38.

[13] 13. Parvin A. Leadership and management in quality assurance : insights from the context of Khulna University, Bangladesh. High Educ Springer Nat [Internet]. 2018; Available from https://doi.org/10.1007/s10734-018-0299-1

[14] 14. Jacobson S. Leadership effects on student achievement and sustained school success. Int J Educ Manag. 2011;

[15] 15. Yirdaw A. Quality of Education in Private Higher Institutions in Ethiopia- The Role of Governance.pdf. SAGE Open. 2016;1-12.

[16] 16. Akhtar NA, Jalil F, Farooq MS, Afzal M, Awan MU. Effect of leadership and academic culture on the implementation of self-assessment manual in public sector universities of Pakistan. J Qual Technol Manag. 2010;6(1):135-52.

[17] 17. Svyatov SA, Adambekova AA, Amankeldi NA. The Realization of Academic Freedom as the Basis of Assurance of Higher Education Quality. Int J Econ Financ [Internet]. 2015;5(2146-4138):80-8. Available from: Http: www.econjournals.com\%0AInternational

[18] 18. Stocia FC, Safta M. University Autonomy and Academic Freedom - Meaning and Legal Basis. Perspect Bus Law J [Internet]. 2013;2(1):192-9. Available from: http://europa.eu/legislation_summaries/education_training_youth/lifelo ng_learning/c11088_ro.htm

[19] 19. Robbins S, Judge TA. Organizational Behavior 15th ed. Zhurnal Eksperimental'noi I Teoreticheskoi Fiziki. 2013.

[20] 20. Turan S, Bektas F. The relationship between school culture and leadership practices. Br J Spec Educ. 2013;

[21] 21. Karadag E, Oztekin-Bayir O. The Effect of Authentic Leadership on School Culture: A Structural Equation Model. Int J Educ Leadersh Manag [Internet]. 2018;6(1):40-75. Available from: http://ezproxy.lib.uconn.edu/login?url=https://search.ebscohost.com/log in.aspx direct $=$ true $\& \mathrm{db}=$ eric $\& \mathrm{AN}=\mathrm{EJ} 1166860 \&$ site=ehost-live

[22] 22. Dill DD. The management of academic culture revisited: Integrating universities in an entrepreneurial age. In: Managing reform in universities: The dynamics of culture, identity, and organizational change. Basingstoke, UK: Palgrave Macmillan; 2012. p. 222-37.

\section{AUTHOR'S BIOGRAPHY}

Susi Hartati from the Department of Education Management - Jakarta State University, Jl. Rawamangun Muka, RT.11 / RW.14, Rawamangun, Pulo Gadung, East Jakarta City, Special Capital Region of Jakarta, Indonesia 13220, Department of Nursing -STIKes Mitra Keluarga, Jl. Pengasinan Rawa Semut, Margahayu, Bekasi Timur, Margahayu, Bekasi Timur, West Java, Indonesia 17113. My area of interest is Human health care, research and development.

Mukhneri Muktar from the Department of Education Management Jakarta State University, Jl. Rawamangun Muka, RT.11 / RW.14, Rawamangun, Pulo Gadung, East Jakarta City, Special Capital Region of Jakarta, Indonesia 13220, Susihartati012@gmail.com. My area of interest is education research and development.

Matin currently affiliated with Department of Education Management - Jakarta State University, J1. Rawamangun Muka, RT.11 / RW.14, Rawamangun, Pulo Gadung, East Jakarta City, Special Capital Region of Jakarta, Indonesia 13220. My area of interest is research and development. 